This is the peer-reviewed, final accepted version for American Mineralogist, published by the Mineralogical Society of America. The published version is subject to change. Cite as Authors (Year) Title. American Mineralogist, in press.

DOI: https://doi.org/10.2138/am-2020-7566. http://www.minsocam.org/

\title{
Major and trace element composition of olivine from magnesian skarns
} and silicate marbles

\author{
Nikolai Nekrylov ${ }^{1}$, Pavel Yu. Plechov ${ }^{1}$, Yulia D. Gritsenko ${ }^{1,2}$, Maxim V. Portnyagin ${ }^{3,4}$, Vasily \\ D. Shcherbakov², Vasily A. Aydov ${ }^{2}$, Dieter Garbe-Schönberg ${ }^{5}$
}

${ }^{1}$ Fersman Mineralogical Museum RAS, Leninsky Av., 18/2, 119071 Moscow, Russia

${ }^{2}$ Lomonosov Moscow State University, Leninskie Gory, 1, 119992 Moscow, Russia

${ }^{3}$ GEOMAR Helmholtz Centre for Ocean Research, Wischhofstr, 1-3, 24148 Kiel, Germany

${ }^{4}$ Vernadsky Institute of geochemistry and analytical chemistry, Kosygina st., 19, 119991

Moscow, Russia

${ }^{5}$ CAU Kiel University, Institute of Geosciences, Ludewig-Meyn-Strasse 10, 24118 Kiel, Germany

\begin{abstract}
Olivine is a major rock-forming mineral in various magmatic and metamorphic rocks and upper mantle. In this paper, we present first high-precision analyses of olivine from 15 samples of magnesian skarns and silicate marbles (MSSM) from the collection of the Fersman Mineralogical Museum (Moscow, Russia). $\mathrm{Mg} \#\left(\mathrm{Mg} /\left(\mathrm{Mg}+\mathrm{Fe}^{2+}\right) * 100\right.$, mol.\%) of olivine from the samples studied varies from 86 to nearly 100 . The main distinctive features of the olivine are anomalously low contents of $\mathrm{Co}(<51 \mu \mathrm{g} / \mathrm{g}), \mathrm{Cr}(<5 \mu \mathrm{g} / \mathrm{g})$ and $\mathrm{Ni}(<44 \mu \mathrm{g} / \mathrm{g})$ and high content of B (23-856 $\mu \mathrm{g} / \mathrm{g})$, which correlate with host-rock compositions. Phosphorus $(5-377 \mu \mathrm{g} / \mathrm{g})$ incorporation in olivine is charge-balanced by the incorporation of $\mathrm{Li}(0.15-61 \mu \mathrm{g} / \mathrm{g})$ and $\mathrm{Na}$ $(<14.3 \mu \mathrm{g} / \mathrm{g})$. Y and REE contents exhibit positive correlations with Na, which suggest that REE
\end{abstract}


This is the peer-reviewed, final accepted version for American Mineralogist, published by the Mineralogical Society of America. The published version is subject to change. Cite as Authors (Year) Title. American Mineralogist, in press.

DOI: https://doi.org/10.2138/am-2020-7566. http://www.minsocam.org/

incorporation into MSSM olivine could occur via charge-balanced coupled substitution with $\mathrm{Na}$ at low temperature and low $a \mathrm{SiO}_{2}$ conditions during MSSM formation. The documented compositional features of olivine from magnesian skarns and silicate marbles can help reconstruct the genesis of the host-rocks and identify xenocrysts of MSSM olivine in magmatic rocks.

Keywords: Olivine; LA-ICP-MS; magnesian skarn; silicate marble; contact metamorphism

\section{Introduction}

Calc-silicate metamorphic and metasomatic rocks, mantle peridotites and mafic igneous rocks are three major rock types of common occurrence of magnesian olivine (Mg\#>80 after Plechov et al. (2018)). Olivine-bearing calc-silicate metamorphic and metasomatic rocks are represented by magnesian skarns and silicate marbles (hereafter referred to as MSSM).

MSSM have similar mineral assemblages, which include carbonates (calcite or dolomite), olivine, phlogopite, diopside, spinel, periclase, clinohumite, and pargasite. Magnesian silicate marbles are difficult to distinguish from magnesian skarns by mineralogy or chemistry. The only major difference between them is their geological position. Magnesian skarns are the product of contact metasomatism and always located in the aureoles of magmatic intrusives (Zharikov et al., 2007), whereas olivine-bearing magnesian silicate marbles are not associated with magmatic rocks. Olivine-bearing magnesian silicate marbles could form during high-grade metamorphism or infiltration metasomatism of dolomites (Bucher and Grapes, 2011).

Olivine-bearing MSSM can form in wide range of pressures (from $\sim 1$ to $\sim 10 \mathrm{kbar}$ ) and temperatures (from $\sim 550$ to $\sim 900{ }^{\circ} \mathrm{C}$ ) as follows from thermodynamic estimates (Bucher and Grapes, 2011; Pertsev, 1974; Zharikov, 1970). The majority of temperature and pressure estimates for olivine growth in carbonate-silicate metamorphic or metasomatic rocks lies in the ranges of $550-700^{\circ} \mathrm{C}$ and $0.5-5 \mathrm{kbar}$, for example: about $600^{\circ} \mathrm{C}$ and from 1 to $5 \mathrm{kbar}$ for 
This is the peer-reviewed, final accepted version for American Mineralogist, published by the Mineralogical Society of America. The published version is subject to change. Cite as Authors (Year) Title. American Mineralogist, in press.

DOI: https://doi.org/10.2138/am-2020-7566. http://www.minsocam.org/

Tazheran, Russia (Doroshkevich et al., 2017), $595{ }^{\circ} \mathrm{C}$ and $1.8 \pm 0.5$ for Twin Lakes pendant, California, USA (Ferry et al., 2011), $680{ }^{\circ} \mathrm{C}$ and $0.5 \mathrm{kbar}$ for Beinn an Dubhaich aureole, Isle of Skye, Scotland (Ferry et al., 2011), and $550{ }^{\circ} \mathrm{C}$ and 2.5 kbar for Gruvaisen, Sweden (Hellingwerf, 1984).

The concentration ranges of major, minor and trace elements in igneous and mantle olivines that are formed at higher temperatures and wider range of pressures are increasingly wellcharacterized (e.g. Arai, 1994; Bussweiler et al., 2019; De Hoog et al., 2010; Foley et al., 2013; Jaques and Foley, 2018; Neave et al., 2018; Rooney et al.,2020; Sobolev et al., 2007; Sobolev et al., 2008; Su et al., 2019; etc.), whereas high-precision data on the composition of olivine from MSSM are very scarce. These published data include several ion probe analyses of B-rich olivine from the Tayozhnoye deposit (Grew et al., 1991), high-precision electron probe analyses of olivine from Kuh-i-Lal deposit (Plechov et al., 2018), some routine (non-high-precision) microprobe analyses of olivine from Tazheran deposit (Doroshkevich et al., 2017), Twin Lakes pendant (California, USA) and Beinn an Dubhaich aureole (Isle of Skye, Scotland) (Ferry et al., 2011) and from primitive magmatic skarns found as xenoliths in magmatic rocks (Fulignati et al., 2005; Gilg et al., 2001; Wenzel et al., 2002). These published data are too scarce to place constraints on the entire variations of olivine composition from MSSM.

In this work we systematically study the content of major, minor and trace elements in olivine from MSSM from different locations. The new data reveal distinctive compositional features of olivine from these rocks, which are manifested in strong enrichment in B combined with depletion in $\mathrm{Ni}, \mathrm{Co}$ and $\mathrm{Cr}$ concentrations in comparison with typical igneous and mantle olivine.

\section{Samples and methods}

We studied a total of 15 samples of magnesian skarn (or silicate marbles in some cases) olivine from nine different locations in three countries (Table 1, Fig. 1) from the collection of the Fersman Mineralogical Museum of the Russian Academy of Sciences (Moscow, Russia). The 
This is the peer-reviewed, final accepted version for American Mineralogist, published by the Mineralogical Society of America. The published version is subject to change. Cite as Authors (Year) Title. American Mineralogist, in press.

DOI: https://doi.org/10.2138/am-2020-7566. http://www.minsocam.org/

samples are representative of both magnesian skarns and silicate marbles. The samples of magnesian skarns are from three classical localities: Nikolai-Maximilian mine, South Urals, Russia (e.g. Bocharnikova et al., 2011), Slyudyanka, Baikal area, Russia (e.g. Aleksandrov and Senin, 2006) and Kukhilal, Tajikistan (Pautov et al., 2018). The sample from Belaya Vyemka, Baikal area, Russia, is a spinel-forsterite marble (Sal'nikova et al., 2007). Five samples are selected from contact zones of carbonate rocks with alkaline intrusives (Tazheran, Russia, and Hodzha-Achkan, Kyrgyzstan) (e.g. Doroshkevich et al., 2017; Pautov et al., 2013) and another five samples are from skarns of phlogopite deposits in Yakutia, Russia, (Katalakh, Emeldhak and Timpton) associated with granites (e.g. Mikhailov, 1997).

High-precision electron microprobe analysis (EPMA) of studied olivine samples was conducted using a wavelength-dispersive X-ray (WDS) electron microprobe JEOL JXA-8230 (Lomonosov Moscow State University) operated at an accelerating voltage of $20 \mathrm{kV}$ and a beam current of 100 nA. San Carlos olivine USNM-111312/444 (Si, Mg, Fe), metal oxides (Ti, Mn, Cr, Al, Ni), wollastonite $(\mathrm{Ca})$ and Durango apatite $(\mathrm{P})$ were used for calibration. The peak signal accumulation time was $120 \mathrm{~s}$ for $\mathrm{Cr}, \mathrm{Ti}, \mathrm{P}, \mathrm{Mn}$ and $\mathrm{Ni}, 180 \mathrm{~s}$ for $\mathrm{Al}, 40 \mathrm{~s}$ for $\mathrm{Ca}$, respectively. Analysis at high beam current and long counting times significantly lowers detection limits of trace element in olivine (Sobolev et al., 2007). Analytical precision, which was determined as 2 standard deviations of multiple repetitive analyses of San Carlos olivine (USNM-111312/444), was estimated to be $41 \mu \mathrm{g} / \mathrm{g}$ for $\mathrm{Ni}, 33 \mu \mathrm{g} / \mathrm{g}$ for Mn, $9 \mu \mathrm{g} / \mathrm{g}$ for Ca, $11 \mu \mathrm{g} / \mathrm{g}$ for P, $12 \mu \mathrm{g} / \mathrm{g}$ for Al, $19 \mu \mathrm{g} / \mathrm{g}$ for $\mathrm{Cr}$ and $8 \mu \mathrm{g} / \mathrm{g}$ for Ti. The results are presented in Supplementary Table 1. San Carlos olivine (USNM-111312/444) was used as a secondary standard (Supplementary table 4).

Major and trace element concentrations of the same olivine samples were also analyzed by laser ablation-inductively coupled plasma-mass spectrometry (LA-ICP-MS) using an Agilent 7900s quadrupole mass-spectrometer coupled with the $193 \mathrm{~nm}$ Excimer Laser-Ablation system GeoLas $^{\mathrm{TM}} \mathrm{HD}$ (Coherent) at the Institute of Geosciences, Kiel University. Instrumental conditions, mass numbers analyzed, and details of data reduction are given in Supplementary 
This is the peer-reviewed, final accepted version for American Mineralogist, published by the Mineralogical Society of America. The published version is subject to change. Cite as Authors (Year) Title. American Mineralogist, in press.

DOI: https://doi.org/10.2138/am-2020-7566. http://www.minsocam.org/

Table 5. In brief, the analyses were performed using two volume ablation cell (ETH Zürich, Switzerland; Fricker et al., 2011) with a carrier gas flow of $0.7 \mathrm{~L} \mathrm{~min}^{-1} \mathrm{He}$ and addition of $14 \mathrm{~mL}$ $\min ^{-1} \mathrm{H}_{2}$. The carrier gas was mixed with $\operatorname{Ar}\left(\sim 1 \mathrm{~L} \mathrm{~min}^{-1}\right)$ prior to introduction to the ICP-MS. The ablation was done with laser beam diameter ranging from 32 to $120 \mu \mathrm{m}$, pulse frequency of $10 \mathrm{~Hz}$ and fluence of $5 \mathrm{~J} / \mathrm{cm}^{2}$. Every analysis comprised $20 \mathrm{~s}$ background measurement (laseroff) and $40 \mathrm{~s}$ of signal measurement (laser-on). The initial data reduction was performed in the GLITTER software (Griffin et al., 2008). The intervals for integration of analytical signal were manually defined to avoid possible contamination by inclusions in olivine, which are usually detectable by strongly elevated concentrations of highly incompatible elements $(\mathrm{K}, \mathrm{Rb}, \mathrm{U}, \mathrm{Pb}$ etc.). The data were initially quantified using glass KL2-G (Jochum et al., 2006) obtained using laser spot of $120 \mu \mathrm{m}$ and $\mathrm{Si}$ as reference element, assuming $\mathrm{SiO}_{2}=40 \mathrm{wt} \%$ in olivine. A secondary standard of olivine MongOL Sh11-2 (Batanova et al., 2019) was used for minor matrix and spot size correction of concentrations of $\mathrm{Si}, \mathrm{Mg}, \mathrm{Fe}, \mathrm{Li}, \mathrm{Na}, \mathrm{Al}, \mathrm{P}, \mathrm{Ca}, \mathrm{Sc}, \mathrm{Ti}, \mathrm{V}, \mathrm{Cr}$, Mn, Co, Ni, Cu, Zn, Ga, Sr, Y, Zr, Dy, Ho, Er, Tm, Yb and Lu (Supplementary Table 3). A correction was applied for the ${ }^{29} \mathrm{Si}^{16} \mathrm{O}$ interference on ${ }^{45} \mathrm{Sc}$ by analysis of synthetic nominally Scfree quartz analysed throughout the measurement session. The final step was proportional adjustment of all concentrations to obtain the sum of $\mathrm{SiO}_{2}, \mathrm{TiO}_{2}, \mathrm{Al}_{2} \mathrm{O}_{3}, \mathrm{FeO}, \mathrm{MnO}, \mathrm{MgO}, \mathrm{CaO}$, $\mathrm{Na}_{2} \mathrm{O}, \mathrm{K}_{2} \mathrm{O}, \mathrm{NiO}, \mathrm{Cr}_{2} \mathrm{O}_{3}, \mathrm{P}_{2} \mathrm{O}_{5}, \mathrm{ZnO}$, and $\mathrm{V}_{2} \mathrm{O}_{3}$ equal to $100 \mathrm{wt} \%$. The results are presented in Supplementary Table 2 .

Eight elements in olivine were measured both by EPMA and LA-ICP-MS methods: $\mathrm{Si}, \mathrm{Fe}, \mathrm{Mg}$, Ti, Al, Mn, Ca, P. Comparison of the data obtained with ca. $5 \mu \mathrm{m}$ (EPMA) and 32-120 $\mu \mathrm{m}$ (LAICP-MS) spots is instructive about the existence of a small scale compositional heterogeneity of the samples. Statistical analysis of this comparison (Ludwig, 1980; York et al., 2004) shows that the linear regressions for $\mathrm{Mg \# ,} \mathrm{Ti,} \mathrm{Mn} \mathrm{and} \mathrm{P}$ do not significantly differ from the line of equal concentrations (1:1 line). MSWD is less than 1.8 for Ti and $\mathrm{P}$, which means that the two analytical methods give statistically indistinguishable results for these elements with probability 
This is the peer-reviewed, final accepted version for American Mineralogist, published by the Mineralogical Society of America. The published version is subject to change. Cite as Authors (Year) Title. American Mineralogist, in press.

DOI: https://doi.org/10.2138/am-2020-7566. http://www.minsocam.org/

of 95\% (Wendt, Carl, 1991; Fig. 2). High MSWD for Mg\# and Mn can be explained by some compositional heterogeneity of the samples, exceeding the analytical precision. There is minor systematic difference between the EPMA and LA-ICP-MS data for Ca, which exceeds 2 standard deviations and is probably linked to $\mathrm{O}^{-}, \mathrm{OH}^{-}$and $\mathrm{N}^{-}$based interferences from $\mathrm{Mg}$ and $\mathrm{Si}$ on minor isotope of ${ }^{43} \mathrm{Ca}$ used for LA-ICP-MS analysis (e.g. Batanova et al., 2019). Therefore, EPMA data for $\mathrm{Ca}$ were preferred in this study. Significantly higher concentrations of $\mathrm{Al}$ obtained by EPMA (Fig. 2) on some samples can result from contamination of olivine surface by $\mathrm{Al}_{2} \mathrm{O}_{3}$ used for polishing (e.g. Batanova et al., 2015). LA-ICP-MS analyses appear to be free of this problem and were used in our study.

\section{Results}

\section{Petrography}

MSSM samples studied are represented by olivine-calcite-spinel (Fig. 3a), olivine-calcitephlogopite (Fig. 3b) and olivine-calcite-spinel-phlogopite (Fig. 3c) mineral associations. Diopside and amphiboles are also occur in some samples as rock-forming minerals. Most samples are unaltered. The primary rock textures are granoblastic and grano-porphyroblastic. Proportions of rock-forming minerals in studied samples vary widely. In general, calcite makes up more than 50 vol.\% in most of them, olivine - up to $50 \mathrm{vol} . \%$, while the contents of spinel and phlogopite are rarely exceed 20 vol.\% of the rocks. Olivine in these samples has idiomorphic shape and size ranging from 0.1 to $2 \mathrm{~mm}$. Some samples $(74607,67723,67792$, and 77329$)$ are strongly serpentinized (up to $90 \%$ of olivine). Olivine in these samples occurs as relics in the serpentine matrix (Fig. 3d). Many olivines studied contain crystal inclusions of the other rockforming minerals and also accessory minerals such as apatite, pyrrhotite, magnetite and ilmenite. Some olivine grains contain abundant fluid inclusions.

\section{Olivine Mg\#}

$\mathrm{Mg \#}$ of studied olivine samples varies from 86.3 to 99.8 , assuming all measured $\mathrm{Fe}$ as $\mathrm{Fe}^{2+}$. Only four studied samples have $\mathrm{Mg \#}<95$, which overlaps with $\mathrm{Mg \#}$ of typical olivine from mantle 
This is the peer-reviewed, final accepted version for American Mineralogist, published by the Mineralogical Society of America. The published version is subject to change. Cite as Authors (Year) Title. American Mineralogist, in press.

DOI: https://doi.org/10.2138/am-2020-7566. http://www.minsocam.org/

xenoliths and magmatic rocks (e.g. De Hoog et al., 2010; Sobolev et al., 2007; Su et al., 2019).

The other samples are more Mg-rich (Fig. 4). The high-Mg composition of the studied olivine samples is in a good agreement with the previous descriptions of olivine from magnesian skarns (e.g. Plechov et al., 2018; Zharikov, 1970). It should be noted that extremely high-Mg olivine (Mg\#>96) can also occur in magmatic rocks (Blondes et al., 2012; Bussweiler et al., 2015; Plechov et al., 2018). However, these olivines are usually interpreted to result post-magmatic processes like oxidation and low-temperature re-equilibration. Some of these previously reported ultra Mg-rich olivines can also be xenocrysts from skarns.

\section{Minor elements (Al, Ca, Mn, Ni, Co, and Cr)}

As minor elements we here consider elements which occur in olivine at concentrations $<10,000$ $\mu \mathrm{g} / \mathrm{g}$ and are typically measured by EPMA in other studies (e.g. Sobolev et al., 2007), i.e. Al, Ca, Mn, Ni, Co and Cr. Some of these elements (e.g., Co, $\mathrm{Cr}$ and $\mathrm{Al}$ ) have concentrations below the detection limit of EPMA in the studied olivine, thus they were analyzed by LA-ICP-MS.

Contents of $\mathrm{Al}, \mathrm{Ca}$ and $\mathrm{Mn}$ in the studied olivine samples vary widely: $\mathrm{Al}$ - from 0.5 to 108 $\mu \mathrm{g} / \mathrm{g} ; \mathrm{Ca}$ - from 40 to $1880 \mu \mathrm{g} / \mathrm{g}$; Mn - from 140 to $4140 \mu \mathrm{g} / \mathrm{g}$ (Fig. 4). The contents of Ca and Al do not show any correlation with the olivine $\mathrm{Mg \#}$ and largely overlap with the typical values for mantle olivine (Fig. 4). Mn content in studied olivine reveals clear negative correlation with

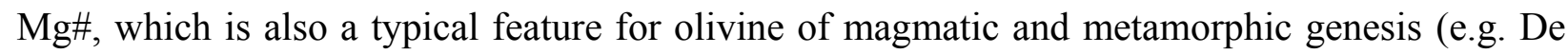
Hoog et al., 2010; Sobolev et al., 2007; Su et al., 2019). Some of studied MSSM olivines with $\mathrm{Mg \#}$ of $\sim 88$ contain twice as much $\mathrm{Mn}$ as the most Mn-rich igneous olivine (Fig. 4). Average $\mathrm{Mn} / \mathrm{Fe}^{*} 100$ of MSSM olivine is $\sim 5.3$, which is significantly higher than typical values for igneous and metamorphic olivine ( 0.5-2) (De Hoog et al., 2010; Sobolev et al., 2007; Su et al., 2019). However, $\mathrm{Mn} / \mathrm{Fe}^{*} 100$ ranges from 1.4 to 20 for different studied samples (Fig. 4) making it difficult to discriminate olivine formed in different environments solely on the base of this parameter. 
This is the peer-reviewed, final accepted version for American Mineralogist, published by the Mineralogical Society of America. The published version is subject to change. Cite as Authors (Year) Title. American Mineralogist, in press.

DOI: https://doi.org/10.2138/am-2020-7566. http://www.minsocam.org/

182

Relative variations of Ni $(0.2-44 \mu \mathrm{g} / \mathrm{g})$ and $\mathrm{Co}(0.3-51 \mu \mathrm{g} / \mathrm{g})$ contents in studied olivine are even larger than for $\mathrm{Al}, \mathrm{Ca}$ and $\mathrm{Mn}$. The contents of both these elements correlate negatively with Mg\# (Fig. 4). However, even the highest Co and Ni contents in olivine from MSSM do not reach the lowest content of these elements in high-Mg\# olivine of mantle and magmatic origin (e.g. De Hoog et al., 2010; Sobolev et al., 2007; Su et al., 2019). Variations of Cr content in the studied olivine samples are the smallest - from 0.5 to $4.9 \mu \mathrm{g} / \mathrm{g}$. The contents do not correlate with olivine $\mathrm{Mg} \#$ and are lower than in high-Mg\# olivine of mantle and magmatic genesis (Fig. $4)$.

\section{Trace element contents in olivine}

Significant amounts of Li, B, Na, Sc, V, Cu, Zn, Sr, Y, Zr, Dy, Ho, Er, Tm, Yb and Lu were detected in the studied olivine samples by LA-ICP-MS (Supplementary Table 2).

Li content varies from 0.15 to $61 \mu \mathrm{g} / \mathrm{g}$ and shows a positive correlation with the content of $\mathrm{P}$, which varies from 5 to $377 \mu \mathrm{g} / \mathrm{g}$ (Fig. 5a).

$\mathrm{Y}(<1.3 \mu \mathrm{g} / \mathrm{g})$, Dy $(<0.04 \mu \mathrm{g} / \mathrm{g})$, Ho $(<0.03 \mu \mathrm{g} / \mathrm{g}), \operatorname{Er}(<0.22 \mu \mathrm{g} / \mathrm{g}), \operatorname{Tm}(<0.08 \mu \mathrm{g} / \mathrm{g}), \mathrm{Yb}(<1.1$ $\mu \mathrm{g} / \mathrm{g})$ and $\mathrm{Lu}(<0.31 \mu \mathrm{g} / \mathrm{g})$ reveal clear positive correlations with $\mathrm{Na}$ content (from 0.15 to 14 $\mu \mathrm{g} / \mathrm{g}$ ) (Fig. 6).

Ti content varies widely from 3.7 to $159 \mu \mathrm{g} / \mathrm{g}$ and does not correlate with $\mathrm{Mg} \#$ or the contents of other elements. On average, Ti in studied MSSM olivine has nearly the same content as olivine from magmatic rocks and mantle xenoliths (Fig. 7a). Boron content in studied MSSM olivine ranges from 23 to $856 \mu \mathrm{g} / \mathrm{g}$ and similarly to Ti does not correlate with Mg\# or with contents of other elements. This B content is 2-3 orders of magnitude higher than in olivine from mantle xenoliths (Fig. 7b).

$\mathrm{Zn}$ in studied MSSM olivine samples has a similar distribution pattern as Mn. Zinc contents for most of studied olivine samples exhibit a clear negative correlation with $\mathrm{Mg} \#$ and increases from 5-10 $\mu \mathrm{g} / \mathrm{g}$ at $\mathrm{Mg} \# 99.8$ to $\sim 380 \mu \mathrm{g} / \mathrm{g}$ at $\mathrm{Mg} \# 86-88$, which is higher than in olivine with similar 
This is the peer-reviewed, final accepted version for American Mineralogist, published by the Mineralogical Society of America. The published version is subject to change. Cite as Authors (Year) Title. American Mineralogist, in press.

DOI: https://doi.org/10.2138/am-2020-7566. http://www.minsocam.org/

Mg\# from igneous and mantle rocks (De Hoog et al., 2010; Kamenetsky et al., 2018; Nekrylov et al., 2018; Neumann et al., 1999; Savelyev et al., 2018; Su et al., 2019) (Fig. 7c). The exceptions are olivine samples PB-15/3, 75567 and 67792, which do not show any dependence of $\mathrm{Zn}$ content on $\mathrm{Mg} \#$, and all have $\mathrm{Zn}$ content below $20 \mu \mathrm{g} / \mathrm{g}$. Fe/Zn ratio in studied olivine varies from $\sim 300$ to $\sim 3000$, which covers the range of $\mathrm{Fe} / \mathrm{Zn}$ in olivine from igneous and mantle rocks (mostly 1000-2000) (Fig. 7c). The measured contents of Sc $(0.4-30 \mu \mathrm{g} / \mathrm{g}), \mathrm{V}(0.03-3.3 \mu \mathrm{g} / \mathrm{g}), \mathrm{Cu}$ (up to $0.3 \mu \mathrm{g} / \mathrm{g}$ ) and $\mathrm{Zr}(0.05-17.7 \mu \mathrm{g} / \mathrm{g}$ ) do not show any clear distribution patterns.

\section{Discussion}

\section{Comparison of olivine from MSSM, magmatic rocks and mantle peridotites}

Magmatic rocks often contain olivine xenocrysts of questionable origin (e.g. Brett et al., 2009; Chayka et al., 2020; Plechov et al., 2017 etc.). Reliable discrimination of the olivine provenance should be based on high quality reference chemical data. Such data exist now for olivine from magmatic silicate rocks (e.g. Foley et al., 2013; Jaques and Foley, 2018; Neave et al., 2018; Sobolev et al., 2007 etc.) and from mantle peridotites (e.g. Bussweiler et al., 2019; De Hoog et al., 2010; Foley et al., 2013; Su et al., 2019). The composition of olivine from high-Mg metamorphic rocks is very poorly known that hampers its identification using chemical criteria.

Studied olivine from MSSM has some distinctive features, which can be used to discriminate it from magmatic and mantle olivine. The most prominent feature is low content of Co $(<51 \mu \mathrm{g} / \mathrm{g})$, $\mathrm{Cr}(<5 \mu \mathrm{g} / \mathrm{g})$ and $\mathrm{Ni}(<44 \mu \mathrm{g} / \mathrm{g})$ in comparison with olivine of the same Mg\# $(>85)$ from mafic magmatic rocks and mantle xenoliths (Fig. 4). This compositional feature is likely related to low $\mathrm{Co}, \mathrm{Cr}$ and $\mathrm{Ni}$ content in sedimentary dolomites (e.g. Carmichael et al., 2008; Ephraim, 2012; Weber, 1964), which are common protoliths for MSSM.

Another distinctive feature of olivine from MSSM is high content of B $(23-856 \mu \mathrm{g} / \mathrm{g})$. Boron content in olivine of other origins is poorly known. The available data indicate concentrations of $<0.5 \mu \mathrm{g} / \mathrm{g}$ in olivine from mantle xenoliths (with one anomalous grain containing $67 \mu \mathrm{g} / \mathrm{g}$ ) (e.g. 
This is the peer-reviewed, final accepted version for American Mineralogist, published by the Mineralogical Society of America. The published version is subject to change. Cite as Authors (Year) Title. American Mineralogist, in press. DOI: https://doi.org/10.2138/am-2020-7566. http://www.minsocam.org/

234 Kaliwoda et al., 2008; Kent and Rossman, 2002), $<21.5 \mu \mathrm{g} / \mathrm{g}$ in olivine from highly 235 metasomatized mantle veins in sub-arc mantle (Bouilhol et al., 2009), $<8 \mu \mathrm{g} / \mathrm{g}$ in subcontinental 236 lithospheric mantle (Chayka et al., 2020), $<23 \mu \mathrm{g} / \mathrm{g}$ in olivine from high-pressure serpentinites 237 (De Hoog et al., 2014), <11 $\mu \mathrm{g} / \mathrm{g}$ in olivine from kimberlites and lamprophyres (Nosova et al., 2017; Nosova et al., 2018), $<165 \mu \mathrm{g} / \mathrm{g}$ in lamproites $(4 \pm 3.5 \mu \mathrm{g} / \mathrm{g}$ without one anomalous olivine crystal) (Chayka et al., 2020), $\sim 4 \mathrm{~g} / \mathrm{g}$ in olivine from Stapafell tholeiite (Jeffries et al., 1995), $\sim 12 \mu \mathrm{g} / \mathrm{g}$ in olivine from Hawaiian ankaramite (Jeffries et al., 1995) and $<1 \mu \mathrm{g} / \mathrm{g}$ in arcrelated magmatic olivine from South Sulawesi (Elburg et al., 2006). All of these data suggest that the observed concentrations of B content in MSSM olivine are anomalously high in comparison with olivine from other environments. Our results are in a good agreement with previously reported data on B enrichment in olivine from magnesian skarns (Grew et al., 1991; Sykes et al., 1994). This compositional feature of olivine from MSSM is also likely linked to the compositions of their protoliths - dolomites, which are strongly enriched in boron (Harder, 1970; Weber, 1964) relative to mafic magmatic and mantle rocks. Such enrichment is caused by the lithophile behavior of boron and its high solubility in aqueous fluids and enrichment in seawater (e.g. Grew, 2015), which makes it abundant in marine sediments.

The new data on the composition of MSSM olivine can be used now to place constraints on the origin of some previously enigmatic olivine xenocrysts of magmatic rocks. For example, we can now discuss the origin of extremely high- $\mathrm{Mg}$ olivine $(\mathrm{Mg} \#>96)$ from lavas of Pian di Celle volcano, Italy (Plechov et al., 2017). In our previous study we argued that this olivine is unlikely of magnesian skarn origin because of low $\mathrm{Mn}$ and $\mathrm{Ca}$ content, not correlating with the composition of host rocks (Plechov et al., 2018). This interpretation requires revision in light of our new data. It is evident from our new data that low Mn and Ca contents of extremely high-Mg olivine described in lavas of Pian di Celle volcano are in fact typical for olivine with $\mathrm{Mg \#}>98$ 
This is the peer-reviewed, final accepted version for American Mineralogist, published by the Mineralogical Society of America. The published version is subject to change. Cite as Authors (Year) Title. American Mineralogist, in press.

DOI: https://doi.org/10.2138/am-2020-7566. http://www.minsocam.org/

259

260

261

262

263

264

265

266

267

268

269

270

271

272

273

274

275

276

277

278

279

280

281

282

283

284

volcanic rocks as well as olivine from primitive magmatic skarns (Fulignati et al., 2005; Gilg et al., 2001; Wenzel et al., 2002).

Wang et al. (2020) have recently described an olivine-rich rock, which they called "jianite". This rock of uncertain origin was found among various Proterozoic felsic volcanic rocks and marbles of Mayihe formation (Ji'an County, Jilin Province, Northeast China) (Wang et al, 2020). LAICP-MS analyses of the olivine from "jianite" revealed extremely high content of B (1763 \pm 23 $\mu \mathrm{g} / \mathrm{g})$ and low contents of $\mathrm{Cr}(0.92 \pm 0.08 \mu \mathrm{g} / \mathrm{g}), \mathrm{Co}(0.58 \pm 0.03 \mu \mathrm{g} / \mathrm{g})$ and $\mathrm{Ni}(0.91 \pm 0.06 \mu \mathrm{g} / \mathrm{g})$ (Wang et al., 2020). Our new data strongly suggest a MSSM-related origin of this olivine. Therefore, we suggest that jianites represent altered olivine-rich magnesian skarns.

\section{Occurrence of low-Ca olivine and monticellite in MSSM}

Olivine from MSSM might be expected to have high $\mathrm{Ca}$ content, because $\mathrm{CaO}$ is a major component for these rocks, which mainly contain more than $50 \mathrm{vol} \%$ of calcite. However, olivine studied in our work has rather low Ca content $(40-1880 \mu \mathrm{g} / \mathrm{g})$, which is similar to $\mathrm{Ca}$ content in olivine from mantle peridotites and significantly lower than Ca content in olivine from magmatic rocks (Fig. 4). It is however important to note that MSSM do not necessarily contain low-Ca olivine; some of them host pure monticellite $\left(\mathrm{MgCaSiO}_{4}\right)$. Both low-Ca olivine and monticellite occur in common MSSM association with calcite, spinel, phlogopite and diopside, sometimes in the same samples (Tracy et al., 1978, Wenzel et al., 2002). Thus, there is no obvious host-rock compositional control on the crystallization of monticellite or olivine in MSSM; both minerals appear to crystallize at relatively high $\mathrm{CaO}$ activity in fluid in contact zones of magmatic intrusions and carbonates.

Stability of monticellite or olivine can be described via the following reaction: $2 \mathrm{MgCaSiO}_{4}$ $+2 \mathrm{CO}_{2}=\mathrm{Mg}_{2} \mathrm{SiO}_{4}+2 \mathrm{CaCO}_{3}+\mathrm{SiO}_{2}$. According to this reaction, there can be also compositional control on the stability of these olivine polymorphs in MSSM. Crystallization of low-Ca olivine in association with calcite should be favored at high $f \mathrm{CO}_{2}$ and low $a \mathrm{SiO}_{2}$. In opposite, 
This is the peer-reviewed, final accepted version for American Mineralogist, published by the Mineralogical Society of America. The published version is subject to change. Cite as Authors (Year) Title. American Mineralogist, in press.

DOI: https://doi.org/10.2138/am-2020-7566. http://www.minsocam.org/

monticellite should be more stable at lower $f \mathrm{CO}_{2}$ and in more $\mathrm{SiO}_{2}$ rich systems, for example, during low-pressure $(<1.5 \mathrm{kbar})$ contact metamorphism of clay-rich limestones.

In addition to system composition, temperature has important control on the incorporation of $\mathrm{Ca}$ in olivine, promoting crystallization of more Ca-rich olivine with increasing temperature (e.g. Adams, Bishop, 1982, Shejwalkar, Coogan, 2013). It is thus likely that the occurrence of monticellite or olivine is also controlled by the temperature of skarn formation so that low-Ca olivine forms at low temperature (generally $<700{ }^{\circ} \mathrm{C}$ ) and is replaced by monticellite at higher temperature (e.g. Fig. 112 in Zharikov, 1970). Indeed some empirical data support this view as monticellite is usually found closer to the contact of scarns with intrusive body (Sinyakov, 1961).

Although more strict thermodynamic analysis is required to more precisely determine the conditions of olivine crystallization in MSSM, our data allowed us to place semi-quantitative constraints on these conditions. We propose that the paradoxically low Ca content in MSSM olivine may reflect specific conditions of the olivine origin, which is crystallization from a $\mathrm{CO}_{2}$ rich fluid at low-temperature and low $a \mathrm{SiO}_{2}$. The olivine is replaced by monticellite at higher temperature, lower $f \mathrm{CO}_{2}$ and at higher $\mathrm{aSiO}_{2}$. This conclusion is in well agreement with the previously published data and thermodynamic modelling on the conditions of MSSM formation (e.g. Bucher and Grapes, 2011; Pertsev, 1974; Zharikov et al., 2007).

\section{Incorporation of trace elements in MSSM olivine}

The observed positive correlation of $\mathrm{P}$ and Li (Fig. 5a) is in a good agreement with the chargebalanced coupled substitution ${ }^{\mathrm{IV}} \mathrm{Si}^{4+}+{ }^{\mathrm{VI}}(\mathrm{Fe}, \mathrm{Mg}){ }^{2+}={ }^{\mathrm{IV}} \mathrm{P}^{5+}+{ }^{\mathrm{VI}} \mathrm{Li}^{+}$(Buseck and Clark, 1984; Woodland et al., 2004). Sodium content reveals a weaker positive correlation with the content of P (Fig. 5b) than that of Li. However, a similar reaction could be the main mechanism of $\mathrm{Na}$ incorporation into the olivine structure (Mallmann et al., 2009). Indeed, molar Li + Na content nearly balance the P content for most of the studied olivine samples from MSSM (Fig. 5c). 
This is the peer-reviewed, final accepted version for American Mineralogist, published by the Mineralogical Society of America. The published version is subject to change. Cite as Authors (Year) Title. American Mineralogist, in press.

DOI: https://doi.org/10.2138/am-2020-7566. http://www.minsocam.org/

Relatively high MSWD value for molar $\mathrm{P}$ and $\mathrm{Li}+\mathrm{Na}$ 1:1 line suggest that there are most likely involved other mechanisms of $\mathrm{P}$ incorporation into the olivine structure along with this one. Excess of $\mathrm{P}$ relative to $\mathrm{Li}$ and $\mathrm{Na}$ observed in some samples (Fig. 5c) can be balanced by the octahedral vacancies via reaction $2^{\mathrm{IV}} \mathrm{Si}^{4+}+{ }^{\mathrm{VI}}(\mathrm{FeMg})^{2+}=2^{\mathrm{IV}} \mathrm{P}^{5+}+{ }^{\mathrm{VI}}(\mathrm{vac})^{0}$ or trivalent cations such as $\mathrm{Cr}, \mathrm{Al}, \mathrm{Fe}^{3+}$ or even $\mathrm{REE}$ via reaction ${ }^{\mathrm{IV}} \mathrm{Si}^{4+}+{ }^{\mathrm{VI}}(\mathrm{FeMg})^{2+}={ }^{\mathrm{IV}} \mathrm{P}^{5+}+{ }^{\mathrm{VI}}(\mathrm{Cr}, \mathrm{Al}, \mathrm{Fe}, \mathrm{Sc}$, $\mathrm{REE}^{3+}$ (e.g. Milman-Barris et al., 2008; Shchipalkina et al., 2019; Shea et al., 2019). However, we found no significant correlation of the P excess with the amount of trivalent cations in MSSM olivine. Therefore, we propose that the former reaction involving octahedral vacancies is the most likely mechanism for the incorporation of the P excess in the MSSM olivine.

The prevailing mechanisms of REE and Y incorporation in olivine structure is a matter of longyear discussion. In a recent study, Burnham and O’Neill (2020) concluded that these elements replace $\mathrm{Mg}^{2+}$ on octahedral sites, but with charge-balance achieved by two different mechanisms: (1) cation vacancies $\left(2 \mathrm{REE}^{3+}+\right.$ vacancy $\left.=3 \mathrm{Mg}^{2+}\right)$; and (2) substitution of $\mathrm{Al}$ for $\mathrm{Si}\left(\mathrm{REE}^{3+}+\mathrm{Al}^{3+}=\mathrm{Mg}^{2+}+\mathrm{Si}^{4+}\right)$. These results confirm conclusions of previous studies (e.g. Colson et al. 1989; Beattie, 1994; Di Stefano et al., 2019; Spandler and O’Neill, 2010), but show that REE can enter olivine simultaneously using different mechanisms, depending on $\mathrm{SiO}_{2}$ and $\mathrm{Al}_{2} \mathrm{O}_{3}$ activity in the system.

Alternatively it was suggested on the basis of thermodynamic calculations that REE substitution on the octahedral site can be charge-balanced by monovalent cations via reaction $2^{\mathrm{VI}}(\mathrm{Fe}, \mathrm{Mg})^{2+}=$ ${ }^{\mathrm{VI}}(\mathrm{H}, \mathrm{Li}, \mathrm{Na})^{+}+{ }^{\mathrm{VI}}(\mathrm{Y}, \mathrm{REE})^{3+}$ (e.g., Colson et al, 1989). The coupled substitution of $2 \mathrm{Mg}$ with REE and proton in olivine $\left(\mathrm{REESiO}_{3}(\mathrm{OH})\right)$ has been shown by Berry et al. (2007). Coupling with $\mathrm{Li}$ was not considered as important mechanism because of low $\mathrm{Li}$ abundance in most olivine-bearing rocks. The mechanism involving $\mathrm{Na}$ has been proposed as potentially significant (e.g., Burnham, O’Neill, 2020), but it was not studied experimentally in sufficient details thus far. 
This is the peer-reviewed, final accepted version for American Mineralogist, published by the Mineralogical Society of America. The published version is subject to change. Cite as Authors (Year) Title. American Mineralogist, in press.

DOI: https://doi.org/10.2138/am-2020-7566. http://www.minsocam.org/

Our data show general positive correlation of Y+REE and Na contents in MSSM olivine (Fig. 6).

This correlation may suggest that Na-rich fluids, from which the olivine crystallized, are also enriched in $\mathrm{REE}+\mathrm{Y}$, and thus this correlation reflects the compositional peculiarity of fluid composition. On the other hand, the correlation may also suggests the coupled incorporation of $\mathrm{REE}+\mathrm{Y}$ and $\mathrm{Na}$ in MSSM olivine. Because only $2 \%$ of all $\mathrm{Na}$ atoms in olivine are required to charge-balance REE $+\mathrm{Y}$ content in olivine (Fig. 6), this mechanism does not contradict the previous conclusion about the coupled $\mathrm{P}, \mathrm{Li}$ and $\mathrm{Na}$ incorporation into the MSSM olivine structure.

Although the exact mechanisms of REE+Y incorporation in MSSM olivine are uncertain, we propose that the coupled substitution of $\mathrm{REE}+\mathrm{Y}$ with monovalent cations, particularly with $\mathrm{Na}$ and $\mathrm{H}$, as well as coupled substitution with $\mathrm{Al}$ in tetrahedral site maybe important in low temperature hydrothermal environment, where olivine crystallize from $\mathrm{CO}_{2}-\mathrm{H}_{2} \mathrm{O}$ fluid at low $\mathrm{SiO}_{2}$ activity. In contrast, the mechanism involving cation vacancies is likely more important at high $\mathrm{SiO}_{2}$ activity in magmatic systems.

We present results of a systematic study of major, minor and trace elements contents in olivine from MSSM. A total of 15 olivine samples originate from nine different locations in three countries and are part of the collection of the Fersman Mineralogical Museum RAS (Russia). Our data allowed us to place constraints on the compositional variations of this olivine, highlight its distinctive features and provide new insights on the incorporation of trace elements in the olivine structure. Our main conclusions are the following:

1) $\mathrm{Mg} \#$ of MSSM olivine varies from $\sim 86$ to nearly 100 . The olivine has anomalously low contents of $\mathrm{Ni}, \mathrm{Co}$ and $\mathrm{Cr}$ and high content of $\mathrm{B}$ inherited from sedimentary carbonate rocks, protoliths for MSSM. These features can be used to discriminate MSSM olivine from magmatic and mantle olivine. 
This is the peer-reviewed, final accepted version for American Mineralogist, published by the Mineralogical Society of America. The published version is subject to change. Cite as Authors (Year) Title. American Mineralogist, in press.

DOI: https://doi.org/10.2138/am-2020-7566. http://www.minsocam.org/

2) Low-Ca olivine in MSSM may reflect crystallization from $\mathrm{CO}_{2}$-rich fluid at relatively low temperature $\left(<700{ }^{\circ} \mathrm{C}\right)$ at low $a \mathrm{SiO}_{2}$. At higher temperature and/or lower $f \mathrm{CO}_{2}$ and higher $a \mathrm{SiO}_{2}$, the olivine is expected to be replaced by monticellite via reaction with calcite and $\mathrm{SiO}_{2}$ in fluid.

3) Strong correlation of the total amount of $\mathrm{Li}$ and $\mathrm{Na}$ with the content of $\mathrm{P}$ suggests a coupled incorporation of these elements in the MSSM olivine via heterovalent substitution at the octahedral and tetrahedral sites: ${ }^{\mathrm{IV}} \mathrm{Si}^{4+}+{ }^{\mathrm{VI}}(\mathrm{Fe}, \mathrm{Mg}){ }^{2+}={ }^{\mathrm{IV}} \mathrm{P}^{5+}+{ }^{\mathrm{VI}}(\mathrm{Li}$, $\mathrm{Na})^{+}$

4) Correlation of REE $+\mathrm{Y}$ and $\mathrm{Na}$ contents suggests that REE $+\mathrm{Y}$ could be incorporated into the MSSM olivine structure via heterovalent substitution at the octahedral site: $2^{\mathrm{VI}}(\mathrm{Fe}$, $\mathrm{Mg})^{2+}={ }^{\mathrm{VI}} \mathrm{Na}^{+}+{ }^{\mathrm{VI}}(\mathrm{Y}, \mathrm{REE})^{3+}$. In contrast to high temperature magmatic systems, this mechanism maybe more important for olivine crystallizing at low temperature in low $\mathrm{aSiO}_{2}$ environments such as in magnesian scarns.

Although our results provide a significant piece of information about the occurrence and composition of olivine in MSSM, we have to admit that the comprehensive understanding of the conditions of olivine crystallization in these rocks is currently missing. In particular, the conditions of crystallization of low-Ca olivine or monticellite in MSSM should be investigated in more details.

Besides MSSM, there is another class of rocks, where compositional variations of olivine were poorly characterized so far. These rocks are carbonatites, which could host olivine similar to that from MSSM by some parameters, for example, by extremely high Mg\# approaching 100 (e.g. Guzmics et al., 2011). Although one can expect an elevated content of $\mathrm{Ca}$ in olivine from magmatic carbonatites (e.g. Di Stefano et al., 2018), there are reports of both relatively high (Guzmics et al., 2011) and very low Ca contents (Xie et al., 2019). The low Ca olivines from carbonatites are currently undistinguishable from olivine of MSSM origin. This could indicate a 
This is the peer-reviewed, final accepted version for American Mineralogist, published by the Mineralogical Society of America. The published version is subject to change. Cite as Authors (Year) Title. American Mineralogist, in press.

DOI: https://doi.org/10.2138/am-2020-7566. http://www.minsocam.org/

387 similar metasomatic origin, or could be due to a lack of precise compositional data. Thus, further

388 systematic study of olivine from carbonatites is required to fill this gap in our knowledge.

\section{Acknowledgements.}

390 We are grateful to U. Westernstroer for assistance with LA-ICP-MS analyses, to Dr. Daniil

391 Popov for constructive discussion, to the editor Dr. Sylvie Demouchy, Dr. Mike Jollands and 392 anonymous reviewer for critical evaluation of this manuscript and constructive comments, which

393 allowed us to significantly improve it. The study was conducted as a part of the Russian 394 government assignment to the Fersman Mineralogical Museum RAS "Diversity of minerals and 395 their associations: new data, development of analytical mineralogy" (AAAA-A18-118228901064). 
This is the peer-reviewed, final accepted version for American Mineralogist, published by the Mineralogical Society of America. The published version is subject to change. Cite as Authors (Year) Title. American Mineralogist, in press.

DOI: https://doi.org/10.2138/am-2020-7566. http://www.minsocam.org/

References:

Adams, G.E., Bishop, F.C. (1982) Experimental investigation of CaMg exchange between olivine, orthopyroxene, and clinopyroxene: potential for geobarometry. Earth and Planetary Science Letters, 57(1), 241-250.

Aleksandrov, S.M., and Senin, V.G. (2006) Genesis and composition of lazurite in magnesian skarns. Geochemistry International, 44(10), 976-988.

Arai, S. (1994) Characterization of spinel peridotites by olivine-spinel compositional relationships: Review and interpretation. Chemical Geology, 113, 191-204.

Batanova, V.G., Sobolev, A.V., Kuzmin, D.V. (2015) Trace element analysis of olivine: high precision analytical method for JEOL JXA-8230 electron probe microanalyser. Chemical Geology, 419, 149-157.

Batanova, V.G., Thompson, J.M., Danyushevsky, L.V., Portnyagin, M.V., Garbe-Schönberg, D., Hauri, E., Kimura, J.-I., Chang, Q., Senda, R., Goemann, K., Chauvel, C., Campillo, S., Ionov, D.A., and Sobolev, A.V. (2019) New Olivine Reference Material for In Situ Microanalysis. Geostandards and Geoanalytical Research, 43(3), 453-473.

Beattie, P. (1994) Systematics and energetics of trace-element partitioning between olivine and silicate melts: Implications for the nature of mineral/melt partitioning. Chemical Geology, 117(1), 57-71.

Berry, A.J., O'Neill, H.S.C., Hermann, J., and Scott, D.R. (2007) The infrared signature of water associated with trivalent cations in olivine. Earth and Planetary Science Letters, 261(1), 134-142.

Blondes, M.S., Brandon, M.T., Reiners, P.W., Page, F.Z. and Kita, N.T. (2012) Generation of forsteritic olivine (Fo99.8) by subsolidus oxidation in basaltic Flows. Journal of Petrology, 53(5), 971-984. 
This is the peer-reviewed, final accepted version for American Mineralogist, published by the Mineralogical Society of America. The published version is subject to change. Cite as Authors (Year) Title. American Mineralogist, in press.

DOI: https://doi.org/10.2138/am-2020-7566. http://www.minsocam.org/

Bocharnikova, T.D., Kholodnov, V.V., and Shagalov, E.S. (2011) Composition and fluid sources of skarns of mineral mines in Kusinsko-Kopansky intrusive complex (Southern Urals). Lithosphera (in russian), 50(5), 124-130.

Bouilhol, P., Burg, J.-P., Bodinier, J.-L., Schmidt, M.W., Dawood, H., and Hussain, S. (2009) Magma and fluid percolation in arc to forearc mantle: Evidence from Sapat (Kohistan, Northern Pakistan). Lithos, 107(1), 17-37.

Brett, R.C., Russell, J.K., Moss, S. (2009) Origin of olivine in kimberlite: Phenocryst or impostor? Lithos, 112, 201-212.

Bucher, K., and Grapes, R. (2011) Petrogenesis of Metamorphic Rocks. 428 p. Springer, Berlin, Heidelberg.

Burnham, A.D., and O’Neill, H.S.C. (2020) Mineral-melt partition coefficients and the problem of multiple substitution mechanisms: insights from the rare earths in forsterite and protoenstatite. Contributions to Mineralogy and Petrology, 175(7).

Buseck, P.R., and Clark, J. (1984) Zaisho-a pallasite containing pyroxene and phosphoran olivine. Mineralogical Magazine, 48(347), 229-235.

Bussweiler, Y., Foley, S.F., Prelević, D. and Jacob, D.E. (2015) The olivine macrocryst problem: new insights from minor and trace element compositions of olivine from Lac de Gras kimberlites, Canada. Lithos, 220, 238-252.

Bussweiler, Y., Giuliani, A., Greig, A., Kjarsgaard, B.A., Petts, D., Jackson, S.E., Barrett, N., Luo, Y. and Pearson, D.G. (2019) Trace element analysis of high-Mg olivine by LA-ICPMS-Characterization of natural olivine standards for matrix-matched calibration and application to mantle peridotites. Chemical Geology, 524, 136-157.

Carmichael, S.K., Ferry, J.M., and McDonough, W.F. (2008) Formation of replacement dolomite in the Latemar carbonate buildup, Dolomites, northern Italy: Part 1. Field relations, mineralogy, and geochemistry. American Journal of Science, 308(7), 851-884. 
This is the peer-reviewed, final accepted version for American Mineralogist, published by the Mineralogical Society of America. The published version is subject to change. Cite as Authors (Year) Title. American Mineralogist, in press.

DOI: https://doi.org/10.2138/am-2020-7566. http://www.minsocam.org/

Chayka, I.F., Sobolev, A.V., Izokh, A.E., Batanova, V.G., Krasheninnikov, S.P., Chervyakovskaya, M.V., Kontonikas-Charos, A., Kutyrev, A.V., Lobastov, B.M., and Chervyakovskiy, V.S. (2020) Fingerprints of Kamafugite-Like Magmas in Mesozoic Lamproites of the Aldan Shield: Evidence from Olivine and Olivine-Hosted Inclusions. Minerals, 10(4), 337.

Colson, R.O., McKay, G.A., and Taylor, L.A. (1989) Charge balancing of trivalent trace elements in olivine and low-Ca pyroxene: A test using experimental partitioning data. Geochimica et Cosmochimica Acta, 53(3), 643-648.

De Hoog, J.C.M., Gall, L., and Cornell, D.H. (2010) Trace-element geochemistry of mantle olivine and application to mantle petrogenesis and geothermobarometry. Chemical Geology, 270(1-4), 196-215.

De Hoog, J.C.M., Hattori, K., and Jung, H. (2014) Titanium- and water-rich metamorphic olivine in high-pressure serpentinites from the Voltri Massif (Ligurian Alps, Italy): evidence for deep subduction of high-field strength and fluid-mobile elements. Contributions to Mineralogy and Petrology, 167(3), 990.

Di Stefano, F., Mollo, S., Blundy, J., Scarlato, P., Nazzari, M., and Bachmann, O. (2019) The effect of $\mathrm{CaO}$ on the partitioning behavior of REE, $\mathrm{Y}$ and Sc between olivine and melt: Implications for basalt-carbonate interaction processes. Lithos, 326-327, 327-340.

Di Stefano, F., Mollo, S., Scarlato, P., Nazzari, M., Bachmann, O., and Caruso, M. (2018) Olivine compositional changes in primitive magmatic skarn environments: A reassessment of divalent cation partitioning models to quantify the effect of carbonate assimilation. Lithos, 316-317, 104-121.

Doroshkevich, A., Sklyarov, E., Starikova, A., Vasiliev, V., Ripp, G., Izbrodin, I., and Posokhov, V. (2017) Stable isotope (C, O, H) characteristics and genesis of the Tazheran brucite marbles and skarns, Olkhon region, Russia. Mineralogy and Petrology, 111(3), 399-416. 
This is the peer-reviewed, final accepted version for American Mineralogist, published by the Mineralogical Society of America. The published version is subject to change. Cite as Authors (Year) Title. American Mineralogist, in press.

DOI: https://doi.org/10.2138/am-2020-7566. http://www.minsocam.org/

Elburg, M., Kamenetsky, V.S., Nikogosian, I., Foden, J., and Sobolev, A.V. (2006) Coexisting high- and low-calcium melts identified by mineral and melt inclusion studies of a subduction-influenced syn-collisional magma from South Sulawesi, Indonesia. Journal of Petrology, 47(12), 2433-2462.

Ephraim, B.E. (2012) Investigation of the geochemical signatures and conditions of formation of metacarbonate rocks occurring within the Mamfe embayment of south-eastern Nigeria. Earth Sciences Research Journal, 16, 121-138.

Ferry, J.M., Ushikubo, T., and Valley, J.W. (2011) Formation of Forsterite by Silicification of Dolomite during Contact Metamorphism. Journal of Petrology, 52(9), 1619-1640.

Foley, S.F., Prelevic, D., Rehfeldt, T., and Jacob, D.E. (2013) Minor and trace elements in olivines as probes into early igneous and mantle melting processes. Earth and Planetary Science Letters, 363, 181-191.

Fricker, M.B., Kutscher, D., Aeschlimann, B., Frommer, J., Dietiker, R., Bettmer, J., Günther, D. (2011) High spatial resolution trace element analysis by LA-ICP-MS using a novel ablation cell for multiple or large samples. International Journal of Mass Spectrometry, 307(1-3), 39-45.

Fulignati, P., Panichi, C., Sbrana, A., Caliro, S., Gioncada, A., and Moro, A.D. (2005) Skarn formation at the walls of the 79AD magma chamber of Vesuvius (Italy): Mineralogical and isotopic constraints. Neues Jahrbuch f??r Mineralogie - Abhandlungen: Journal of Mineralogy and Geoche, 181(1), 53-66.

Gilg, H.A., Lima, A., Somma, R., Belkin, H.E., De Vivo, B., and Ayuso, R.A. (2001) Isotope geochemistry and fluid inclusion study of skarns from Vesuvius. Mineralogy \& Petrology, 73(1-3), 145-176.

Grew, E.S. (2015) Boron - the crustal element. Elements, 11(3), 162-163. 
This is the peer-reviewed, final accepted version for American Mineralogist, published by the Mineralogical Society of America. The published version is subject to change. Cite as Authors (Year) Title. American Mineralogist, in press.

DOI: https://doi.org/10.2138/am-2020-7566. http://www.minsocam.org/

Grew, E.S., Pertsev, N.N., Boronikhin, V.A., Borisovskiy, S.Y., Yates, M.G., and Marquez, N. (1991) Serendibite in the Tayozhnoye deposit of the Aldan Shield, eastern Siberia, U.S.S.R. American Mineralogist, 76(5-6), 1061-1080.

Griffin, W.L. (2008) GLITTER: data reduction software for laser ablation ICP-MS. Laser Ablation ICP-MS in the Earth Sciences: Current practices and outstanding issues, 308311.

Guzmics, T., Mitchell, R.H., Szabó, C., Berkesi, M., Milke, R., and Abart, R. (2011) Carbonatite melt inclusions in coexisting magnetite, apatite and monticellite in Kerimasi calciocarbonatite, Tanzania: melt evolution and petrogenesis. Contributions to Mineralogy and Petrology, 161(2), 177-196.

Harder, H. (1970) Boron content of sediments as a tool in facies analysis. Sedimentary Geology, $4(1), 153-175$.

Hellingwerf, R.H. (1984) Paragenetic zoning and genesis of Cu-Zn-Fe-Pb-As sulfide skarn ores in a Proterozoic rift basin, Gruvaasen, western Bergslagen, Sweden. Economic Geology, 79(4), 696-715.

Jaques, A.L., and Foley, S.F. (2018) Insights into the petrogenesis of the West Kimberley lamproites from trace elements in olivine. Mineralogy and Petrology, 112(2), 519-537.

Jeffries, T.E., Perkins, W.T., and Pearce, N.J.G. (1995) Measurements of trace elements in basalts and their phenocrysts by laser probe microanalysis inductively coupled plasma mass spectrometry (LPMA-ICP-MS). Chemical Geology, 121(1), 131-144.

Jochum, K.P., Stoll, B., Herwig, K., Willbold, M., Hofmann, A.W., Amini, M., Aarburg, S., Abouchami, W., Hellebrand, E., Mocek, B., Raczek, I., Stracke, A., Alard, O., Bouman, C., Becker, S., Dücking, M., Brätz, H., Klemd, R., de Bruin, D., Canil, D., Cornell, D., de Hoog, C.-J., Dalpé, C., Danyushevsky, L., Eisenhauer, A., Gao, Y., Snow, J.E., Groschopf, N., Günther, D., Latkoczy, C., Guillong, M., Hauri, E.H., Höfer, H.E., Lahaye, Y., Horz, K., Jacob, D.E., Kasemann, S.A., Kent, A.J.R., Ludwig, T., Zack, T., 
This is the peer-reviewed, final accepted version for American Mineralogist, published by the Mineralogical Society of America. The published version is subject to change. Cite as Authors (Year) Title. American Mineralogist, in press.

DOI: https://doi.org/10.2138/am-2020-7566. http://www.minsocam.org/

Mason, P.R.D., Meixner, A., Rosner, M., Misawa, K., Nash, B.P., Pfänder, J., Premo, W.R., Sun, W.D., Tiepolo, M., Vannucci, R., Vennemann, T., Wayne, D., and Woodhead, J.D. (2006) MPI-DING reference glasses for in situ microanalysis: New reference values for element concentrations and isotope ratios. Geochemistry, Geophysics, Geosystems, 7(2).

Kaliwoda, M., Ludwig, T., and Altherr, R. (2008) A new SIMS study of Li, Be, B and d7Li in mantle xenoliths from Harrat Uwayrid (Saudi Arabia). Lithos, 106(3-4), 261-279.

Kamenetsky, V.S., Zelenski, M., Gurenko, A., Portnyagin, M., Ehrig, K., Kamenetsky, M., Churikova, T., and Feig, S. (2018) Silicate-sulfide liquid immiscibility in modern arc basalt (Tolbachik volcano, Kamchatka): Part II. Composition, liquidus assemblage and fractionation of the silicate melt. Chemical Geology, 478, 112-130.

Kent, A.J.R., and Rossman, G.R. (2002) Hydrogen, lithium, and boron in mantle-derived olivine: The role of coupled substitutions. American Mineralogist, 87(10), 1432-1436.

Ludwig, K.R. (1980) Calculation of uncertainties of U-Pb isotope data. Earth and Planetary Science Letters, 46(2), 212-220.

Mallmann, G., O'Neill, H.S.C., and Klemme, S. (2009) Heterogeneous distribution of phosphorus in olivine from otherwise well-equilibrated spinel peridotite xenoliths and its implications for the mantle geochemistry of lithium. Contributions to Mineralogy and Petrology, 158(4), 485-504.

Mikhailov, D.A. (1997) Chapter 9 The Aldan terrain. In D.V. Rundqvist, and C. Gillen, Eds. Developments in Economic Geology, 30, p. 195-210. Elsevier.

Milman-Barris, M.S., Beckett, J.R., Baker, M.B., Hofmann, A.E., Morgan, Z., Crowley, M.R., Vielzeuf, D., and Stolper, E. (2008) Zoning of phosphorus in igneous olivine. Contributions to Mineralogy and Petrology, 155(6), 739-765. 
This is the peer-reviewed, final accepted version for American Mineralogist, published by the Mineralogical Society of America. The published version is subject to change. Cite as Authors (Year) Title. American Mineralogist, in press.

DOI: https://doi.org/10.2138/am-2020-7566. http://www.minsocam.org/

545

Neave, D.A., Shorttle, O., Oeser, M., Weyer, S., and Kobayashi, K. (2018) Mantle-derived trace element variability in olivines and their melt inclusions. Earth and Planetary Science Letters, 483, 90-104.

Nekrylov, N., Popov, D., Plechov, P., Shcherbakov, V., Danyushevsky, L., and Dirksen, O.V. (2018) Garnet-pyroxenite-derived end-member magma type in Kamchatka: evidence from composition of olivine and olivine-hosted melt inclusions in Holocene rocks of Kekuknaisky volcano. Petrology, 26(4), 329-350.

Neumann, E.R., Wulff-Pedersen, E., Simonsen, S.L., Pearson, N.J., Marti, J., and Mitjavila, J. (1999) Evidence for fractional crystallization of periodically refilled magma chambers in Tenerife, Canary Islands. Journal of Petrology, 40(7), 1089-1123.

Nosova, A.A., Dubinina, E.O., Sazonova, L.V., Kargin, A.V., Lebedeva, N.M., Khvostikov, V.A., Burmii, Z.P., Kondrashov, I.A., and Tret'yachenko, V.V. (2017) Geochemistry and oxygen isotopic composition of olivine in kimberlites from the Arkhangelsk province: Contribution of mantle metasomatism. Petrology, 25(2), 150-180.

Nosova, A.A., Sazonova, L.V., Kargin, A.V., Smirnova, M.D., Lapin, A.V., and Shcherbakov, V.D. (2018) Olivine in ultramafic lamprophyres: chemistry, crystallisation, and melt sources of Siberian Pre- and post-trap aillikites. Contributions to Mineralogy and Petrology, 173(7), 55

Pautov, L.A., Karpenko, V.Y., and Agakhanov, A.A. (2013) Baratovite-Katayamalite minerals from the Hodzha-Achkan alcaline massif (Kirgizia) New data on minerals, 48, 12-36.

Pautov, L.A., Mirakov, M.A., Shodibekov, M.A., Fayziev, A.R., Khvorov, P.V., and Makhmadsharif, S. (2018) Occurrence of Tungstenite-2H in magnesian skarns of gem quality spinel deposit Kukhi-Lal (South-Western Pamir, Tajikistan). New data on minerals, 52(4), 91-101.

Pertsev, N.N. (1974) Skarns as magmatic and postmagmatic formations. International Geology Review, 16(5), 572-582. 
This is the peer-reviewed, final accepted version for American Mineralogist, published by the Mineralogical Society of America. The published version is subject to change. Cite as Authors (Year) Title. American Mineralogist, in press.

DOI: https://doi.org/10.2138/am-2020-7566. http://www.minsocam.org/

Plechov, P.Y., Nekrylov, N.A., Shcherbakov, V.D., and Tikhonova, M.S. (2017) Extreme-Mg olivines from venancite lavas of Pian di Celle volcano (Italy). Doklady Earth Sciences, 474(1), 507-510.

Plechov, P.Y., Shcherbakov, V.D., and Nekrylov, N.A. (2018) Extremely magnesian olivine in igneous rocks. Russian Geology and Geophysics, 59(12), 1702-1717.

Purton, J.A., Allan, N.L., and Blundy, J.D. (1997) Calculated solution energies of heterovalent cations in forsterite and diopside: Implications for trace element partitioning. Geochimica et Cosmochimica Acta, 61(18), 3927-3936.

Rooney, T., Girard, G., Tappe S. (2020) The impact on mantle olivine resulting from carbonated silicate melt interaction. Contributions to Mineralogy and Petrology, 175, 56.

Sal'nikova, E.B., Kotov, A.B., Levitskii, V.I., Reznitskii, L.Z., Mel'nikov, A.I., Kozakov, I.K., Kovach, V.P., Barash, I.G., and Yakovleva, S.Z. (2007) Age constraints of hightemperature metamorphic events in crystalline complexes of the Irkut block, the Sharyzhalgai ledge of the Siberian platform basement: Results of the U-Pb single zircon dating. Stratigraphy and Geological Correlation, 15(4), 343-358.

Savelyev, D.P., Kamenetsky, V.S., Danyushevsky, L.V., Botcharnikov, R.E., Kamenetsky, M.B., Park, J.-W., Portnyagin, M.V., Olin, P., Krasheninnikov, S.P., Hauff, F., and Zelenski, M.E. (2018) Immiscible sulfide melts in primitive oceanic magmas: Evidence and implications from picrite lavas (Eastern Kamchatka, Russia). American Mineralogist, 103(6), 886-898.

Shchipalkina, N.V., Pekov, I.V., Zubkova, N.V., Koshlyakova, N.N., and Sidorov, E.G. (2019) Natural forsterite strongly enriched by arsenic and phosphorus: chemistry, crystal structure, crystal morphology and zonation. Physics and Chemistry of Minerals, 46(9), 889-898.

Shea, T., Hammer, J.E., Hellebrand, E., Mourey, A.J., Costa, F., First, E.C., Lynn, K.J., and Melnik, O. (2019) Phosphorus and aluminum zoning in olivine: contrasting behavior of 
This is the peer-reviewed, final accepted version for American Mineralogist, published by the Mineralogical Society of America. The published version is subject to change. Cite as Authors (Year) Title. American Mineralogist, in press.

DOI: https://doi.org/10.2138/am-2020-7566. http://www.minsocam.org/ two nominally incompatible trace elements. Contributions to Mineralogy and Petrology, $174(10), 85$.

Shejwalkar, A., Coogan, L.A. (2013) Experimental calibration of the roles of temperature and composition in the Ca-in-olivine geothermometer at 0.1 MPa. Lithos, 177, 54-60.

Sinyakov, V.I. (1961) On the geological structure and ore mineralogy of Lespromkhoznoe deposit (Gornaya Shoriya). Geology of ore deposits, 37-53 (in russian).

Sobolev, A.V., Hofmann, A.W., Kuzmin, D.V., Yaxley, G.M., Arndt, N.T., Chung, S.-L., Danyushevsky, L.V., Elliott, T., Frey, F.A., Garcia, M.O., Gurenko, A.A., Kamenetsky, V.S., Kerr, A.C., Krivolutskaya, N.A., Matvienkov, V.V., Nikogosian, I.K., Rocholl, A., Sigurdsson, I.A., Sushchevskaya, N.M., and Teklay, M. (2007) The amount of recycled crust in sources of mantle-derived melts. Science, $316(5823$ (20 April)), 412-417.

Sobolev, N.V., Logvinova, A.M., Zedgenizov, D.A., Pokhilenko, N.P., Kuzmin, D.V., and Sobolev, A.V. (2008) Olivine inclusions in Siberian diamonds: high-precision approach to minor elements. European Journal of Mineralogy, 20(3), 305-315.

Spandler, C., and O’Neill, H.S.C. (2010) Diffusion and partition coefficients of minor and trace elements in San Carlos olivine at $1,300^{\circ} \mathrm{C}$ with some geochemical implications. Contributions to Mineralogy and Petrology, 159(6), 791-818.

Su, B., Chen, Y., Mao, Q., Zhang, D., Jia, L.-H., and Guo, S. (2019) Minor elements in olivine inspect the petrogenesis of orogenic peridotites. Lithos, 344-345, 207-216.

Sykes, D., Rossman, G.R., Veblen, D.R., and Grew, E.S. (1994) Enhanced H and F incorporation in borian olivine. American Mineralogist, 79(9-10), 904-908.

Tracy, R.J., Jaffe, H.W., Robinson, P. (1978) Monticellite marble at Cascade Mountain, Adirondack Mountains, New York. American Mineralogist, 63(9-10), 991-999.

Wang, Y., He, M., Yan, W., Yang, M., and Liu, X. (2020) Jianite: Massive Dunite Solely Made of Virtually Pure Forsterite from Ji'an County, Jilin Province, Northeast China. Minerals, $10(3), 220$. 
This is the peer-reviewed, final accepted version for American Mineralogist, published by the Mineralogical Society of America. The published version is subject to change. Cite as Authors (Year) Title. American Mineralogist, in press.

DOI: https://doi.org/10.2138/am-2020-7566. http://www.minsocam.org/

623

Weber, J.N. (1964) Trace element composition of dolostones and dolomites and its bearing on the dolomite problem. Geochimica et Cosmochimica Acta, 28(10), 1817-1868.

Wendt, I., Carl, C. (1991) The statistical distribution of the mean squared weighted deviation. Chemical Geology: Isotope Geoscience Section, 86(4), 275-285.

Wenzel, T., Baumgartner, L.P., Brugmann, G.E., Konnikov, E.G., and Kislov, E.V. (2002) Partial melting and assimilation of dolomitic xenoliths by mafic magma: the IokoDovyren intrusion (North Baikal region, Russia). Journal of Petrology, 43(11), 20492074.

Woodland, A.B., Seitz, H.M., and Yaxley, G.M. (2004) Varying behaviour of Li in metasomatised spinel peridotite xenoliths from western Victoria, Australia. Lithos, 75(1), $55-66$.

Xie, Y., Qu, Y., Zhong, R., Verplanck, P.L., Meffre, S., and Xu, D. (2019) The $\sim 1.85 \mathrm{Ga}$ carbonatite in north China and its implications on the evolution of the Columbia supercontinent. Gondwana Research, 65, 125-141.

York, D., Evensen, N.M., Martınez, M.L., De Basabe Delgado, J. (2004) Unified equations for the slope, intercept, and standard errors of the best straight line. American Journal of Physics, 72(3), 367-375.

Zharikov, V.A. (1970) Skarns (Part I). International Geology Review, 12(5), 541-559.

Zharikov, V.A., Pertsev, N.N., Rusinov, V.L., Callegari, E., and Fettes, D.J. (2007) Metasomatism and metasomatic rocks. In D. Fettes, and J. Desmons, Eds. Metamorphic Rocks: A Classification and Glossary of Terms: Recommendations of the International Union of Geological Sciences Subcommission on the Systematics of Metamorphic Rocks, p. 17. Cambridge University Press. 
This is the peer-reviewed, final accepted version for American Mineralogist, published by the Mineralogical Society of America. The published version is subject to change. Cite as Authors (Year) Title. American Mineralogist, in press.

DOI: https://doi.org/10.2138/am-2020-7566. http://www.minsocam.org/

\section{Figure captions:}

648 Fig. 1. Schematic map with marked sampling localities. Numbers (N), sample names and locations correspond to those in Table 1. The map is drawn using https://mapchart.net website.

Fig. 2. Comparison of EPMA and LA-ICP-MS data on the olivine composition from the same correspond to two standard deviations. Uncertainties of primary standards are not included, because they contribute insignificantly to the total uncertainty (Batanova et al., 2015, 2019). Linear regressions are calculated following the method of York et al. (2004), uncertainties of the regressions are calculated following Ludwig (1980).

Fig. 3. Petrographic features of studied MSSM samples. a - Ol-Cal-Sp association of the PB-153 sample in plane polarized (left) and crossed polarized (right) light; $\mathrm{b}$ - Ol-Cal-Phl association of the WS-15-4b sample in in plane polarized (left) and crossed polarized (right) light; c - backscattering electrons image of Ol-Cal-Sp-Phl association of the 50363 sample with spots of LAICP-MS analyses; $d$ - back-scattering electrons image of highly serpentinized olivine of the 74186 sample with spots of LA-ICP-MS analyses. Sp - spinel, Cal - calcite, Phl - phlogopite, Srp - serpentine, Mt - magnetite, Ilm - ilmenite.

Fig. 4. Minor elements (Mn, Ni, Al, Ca, Cr and $\mathrm{Co}$ ) contents in studied skarn and silicate marble olivine samples (LA-ICP-MS data, Supplementary Table 2) in comparison with magmatic (De Hoog et al., 2010; Sobolev et al., 2007) and mantle olivine (De Hoog et al., 2010; Su et al., 2019). Sample names correspond to those in Table 1 and on Figure 1.

Fig. 5. P, Li and Na content in studied olivine samples $(\mathrm{a}, \mathrm{b})$ and comparison of $\mathrm{Li}+\mathrm{Na}$ with $\mathrm{P}$ concentrations calculated as atoms per formula unit (apfu) (c). Sample names correspond to those in Table 1 and on Figure 1. Linear regression for the comparison of $\mathrm{Li}+\mathrm{Na}$ with $\mathrm{P}$ (in apfu) is calculated following the method of York et al. (2004), uncertainties of the regression are calculated following Ludwig (1980). 
This is the peer-reviewed, final accepted version for American Mineralogist, published by the Mineralogical Society of America. The published version is subject to change. Cite as Authors (Year) Title. American Mineralogist, in press.

DOI: https://doi.org/10.2138/am-2020-7566. http://www.minsocam.org/

672 Fig. 6. Dependence of measured $\mathrm{Y}, \mathrm{Dy}, \mathrm{Yb}$ and total REE contents in studied olivine samples

673 from the content of Na. Sample names correspond to those in Table 1 and on Figure 1.

674 Fig. 7. Ti (a), B (b) and Zn (c) contents versus Mg\# in studied olivine samples. Sample names 675 correspond to those in Table 1 and on Figure 1. Ti and Zn contents in mantle olivine are from De 676 Hoog et al. (2010) and Su et al. (2019), B - on the basis of Kent and Rossman (2002) and 677 Chayka et al. (2020) data; Ti and Zn contents in magmatic olivine are shown for olivine from 678 Baffin Island picrites (De Hoog et al., 2010), basalts from Canary Islands (Neumann et al., 679 1999), MORBs (Savelyev et al., 2018), arc basalts (Kamenetsky et al., 2018) and back-arc basalt 680 (Nekrylov et al., 2018). B contents in magmatic olivine are shown only for kimberlites, 681 lamproites and lamprophyres (Chayka et al., 2020; Nosova et al., 2017; Nosova et al., 2018) due 682 to the lack of data on other magmatic suites. 
Table 1: List of studied MSSM samples from Fersman Mineralogical Museum RAS.

\begin{tabular}{|c|c|c|c|}
\hline $\mathrm{N}$ & $\begin{array}{c}\text { Sample } \\
\#\end{array}$ & Location & Short sample description \\
\hline 1 & $\begin{array}{l}\text { WS-15- } \\
4 \mathrm{~b}\end{array}$ & Belaya Vyemka (Russia) & Phl-Ol skarn \\
\hline 2 & PB-15-1 & Tazheran Massif (Russia) & Ol-Sp skarn \\
\hline 3 & PB-15-3 & Tazheran Massif, Perovskite mine (Russia) & Ol-Sp skarn \\
\hline 4 & 74607 & Tazheran Massif (Russia) & Fo with Di \\
\hline 5 & 75567 & Tazheran Massif (Russia) & Fo \\
\hline 6 & 62949 & Kukhilal (Tajikistan) & Ol Mg-skarn \\
\hline 7 & 82188 & Kukhilal (Tajikistan) & Ol Mg-skarn \\
\hline 8 & 67723 & Katalakh, gallery \#2 (Russia) & Ol Mg-skarn \\
\hline 9 & 67792 & $\begin{array}{l}\text { Emeldzhak ore deposit, Taborny site, Gorely mine } \\
\text { (Russia) }\end{array}$ & Ol Mg-skarn \\
\hline 10 & 74186 & Emeldzhak ore deposit (Russia) & Amp-Ol Mg-skarn \\
\hline 11 & 68009 & Timpton river, Leglier mine (Russia) & Amp-Ol Mg-skarn \\
\hline 12 & 77329 & Timpton river, Kurung-Honku (Russia) & Phl-Ol Mg-skarn \\
\hline 13 & 32900 & Nikolai-Maximilian mine (Russia) & Fo with Cal, Prv and Di \\
\hline 14 & 50363 & Hodzha-Achkan alkaline massif, Tilbe pass (Kyrgyzstan) & Fo \\
\hline 15 & 81924 & Slyudyanka, Uluntui pad' (Russia) & Fo \\
\hline
\end{tabular}


Figure 3

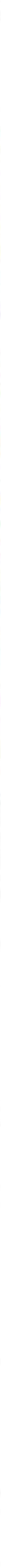


Figure 4

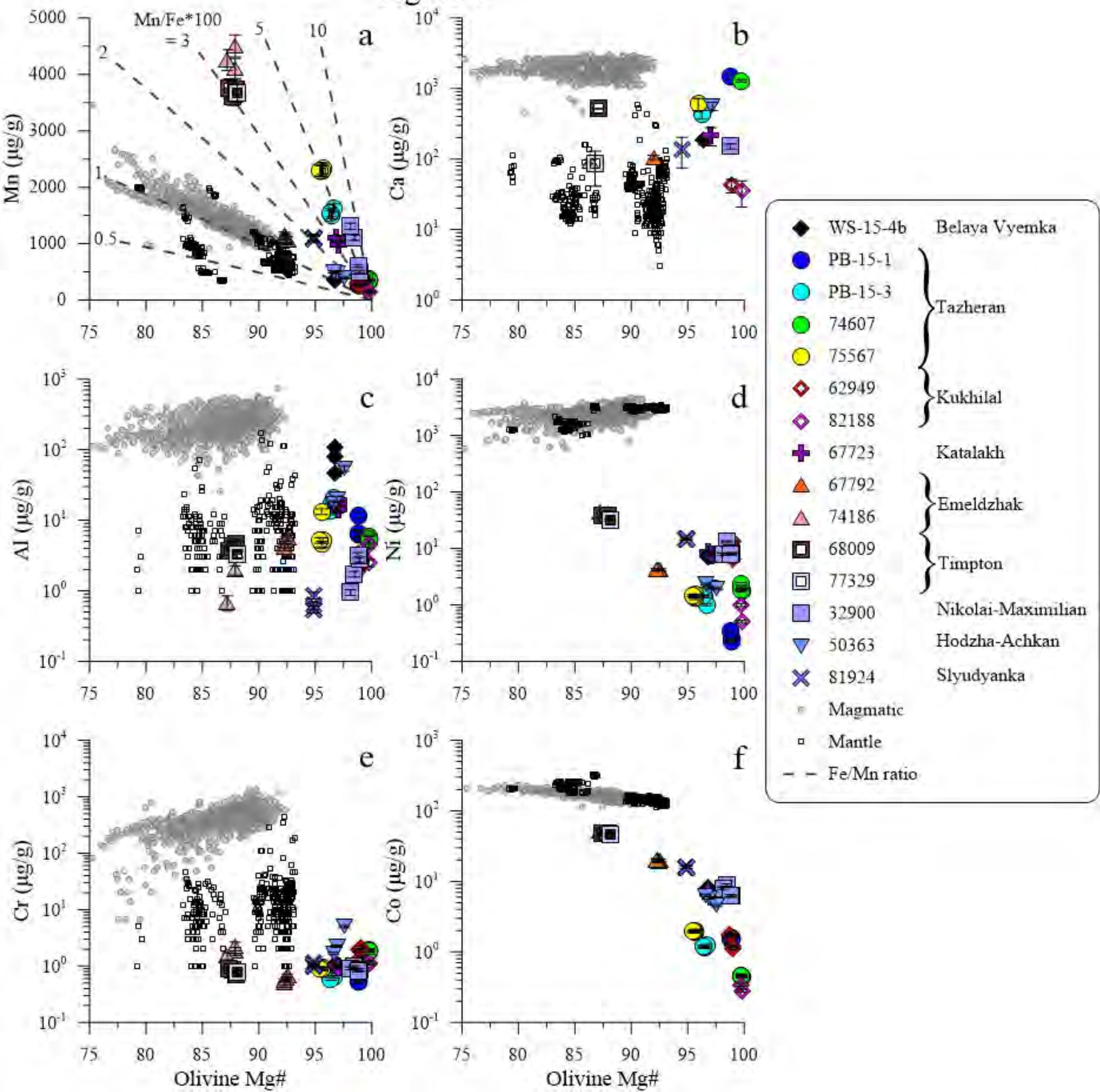



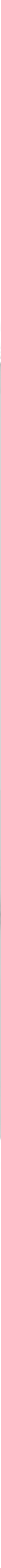

- WS-15-4b Belaya Vyemka

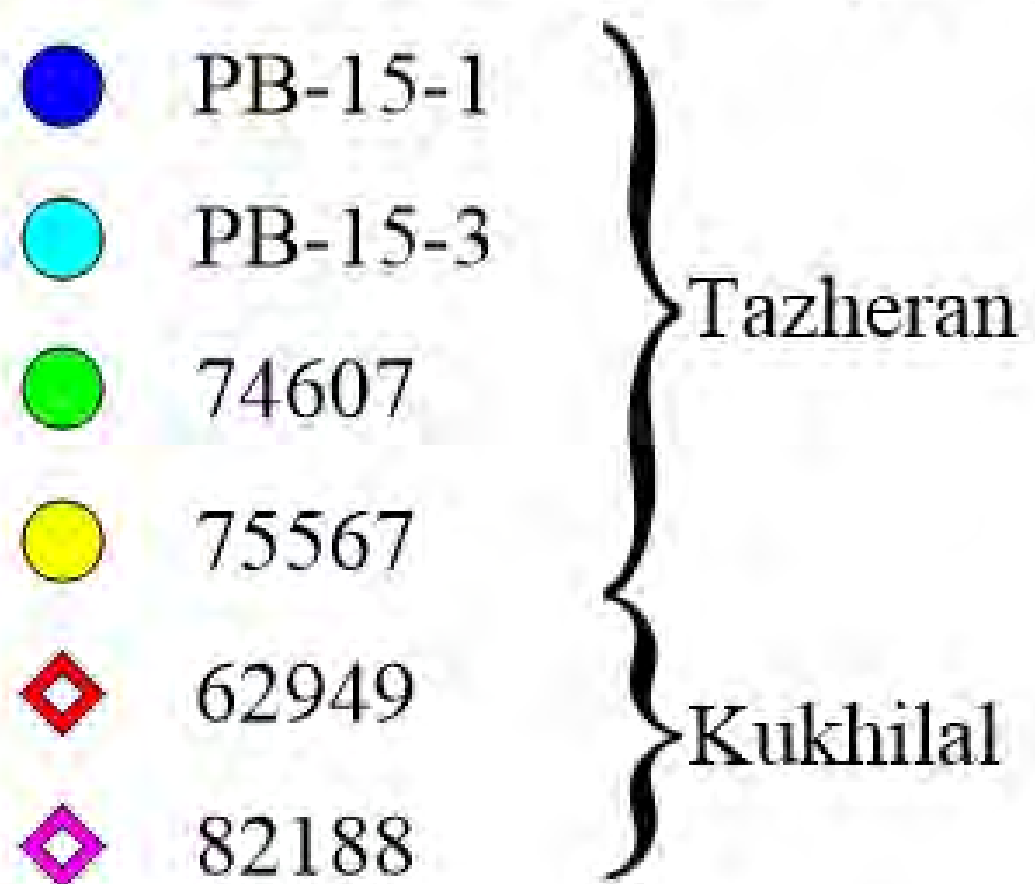

$+67723$

Katalakh

$\left.\begin{array}{lll}\triangle & 67792 \\ \triangle & 74186 \\ \text { 口 } & 68009 \\ \text { 回 } & 77329\end{array}\right\}$ Emeldzhak

$\square \quad 32900$

Nikolai-Maximilian

$\nabla 50363$

Hodzha-Achkan

× 81924

Slyudyanka

- 1:1 line

Linear regression

(York et al., 2004) 
Figure 6
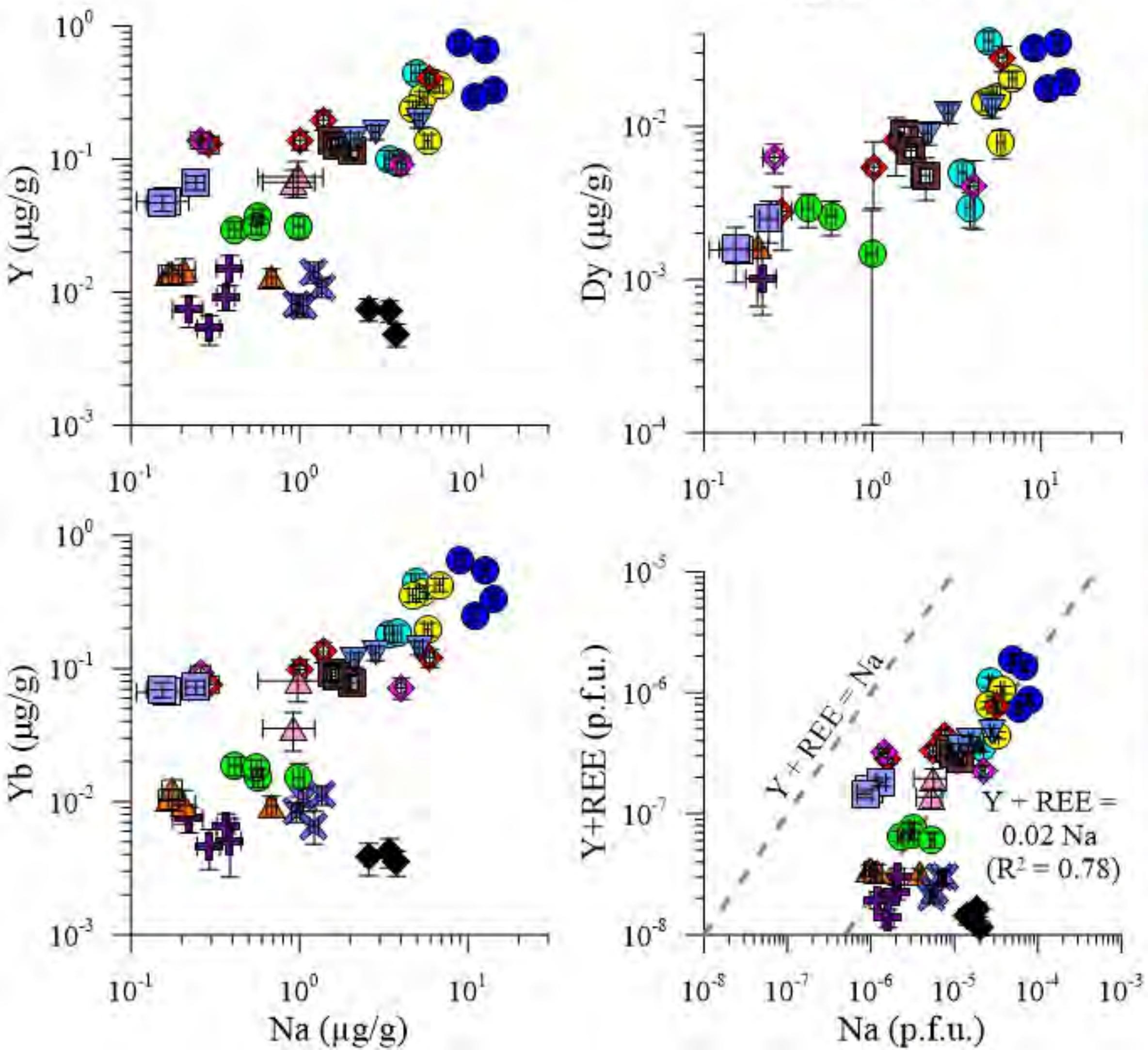

- WS-15-4b Belaya Vyemka

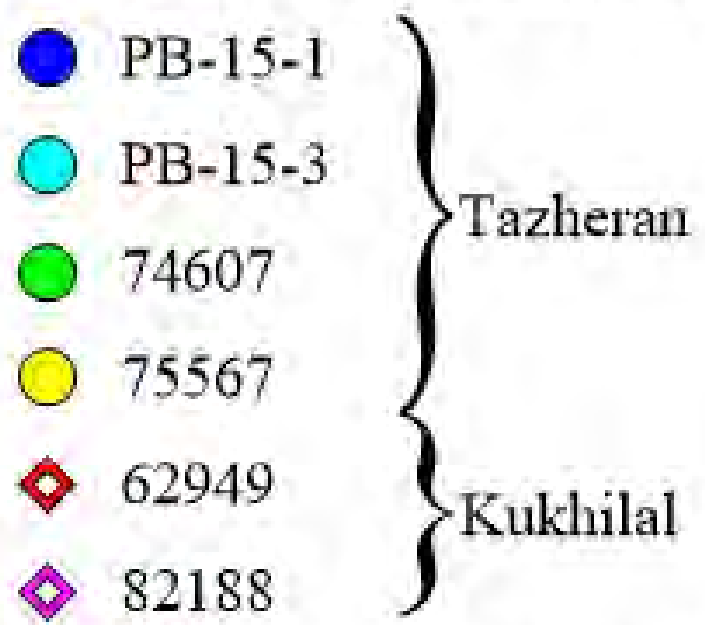

A 67723 Katalakh

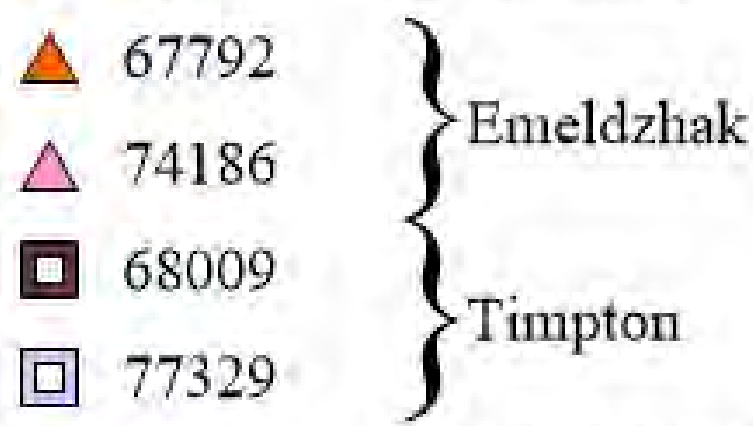

$\square 32900 \quad$ Nikolai-Maximilian

$\nabla 50363 \quad$ Hodzha-Achkan

× $81924 \quad$ Slyudyanka 

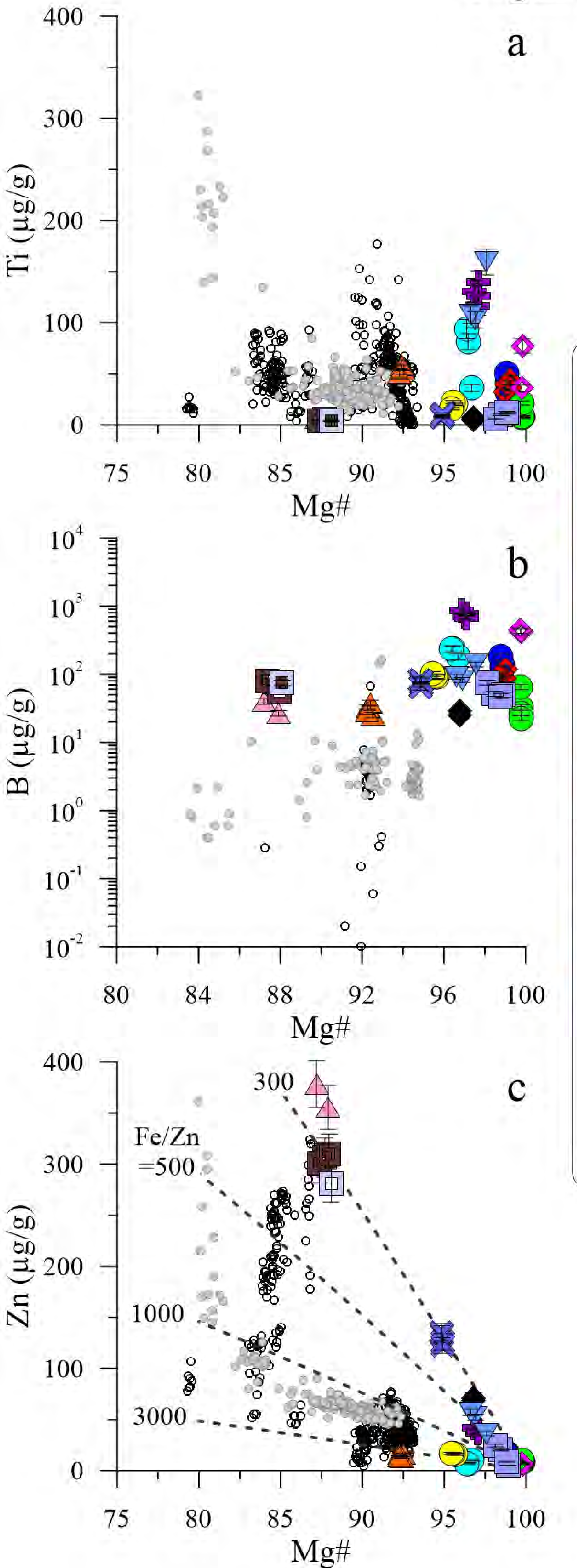

- WS-15-4b Belaya Vyemka

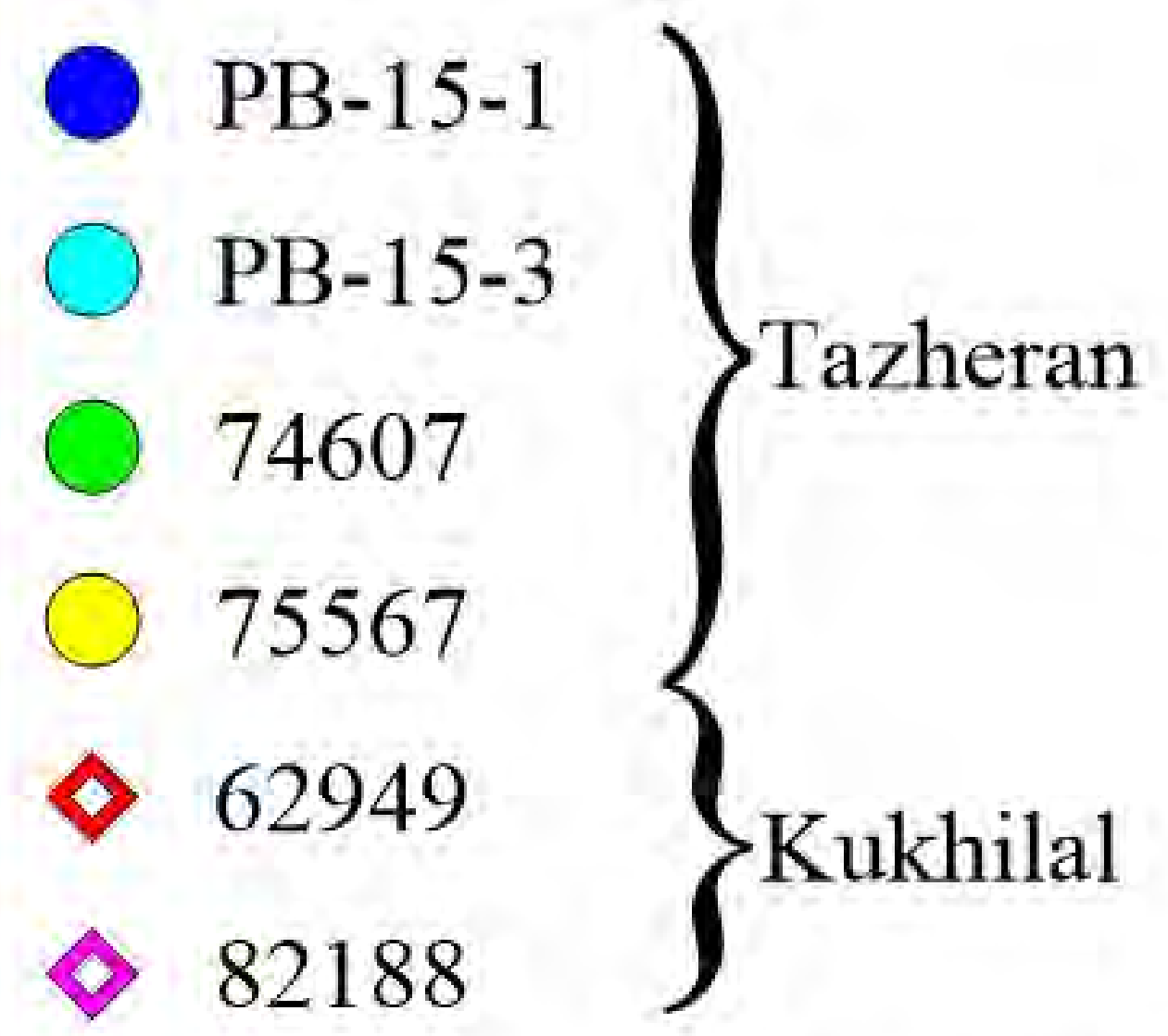

+ 67723 Katalakh

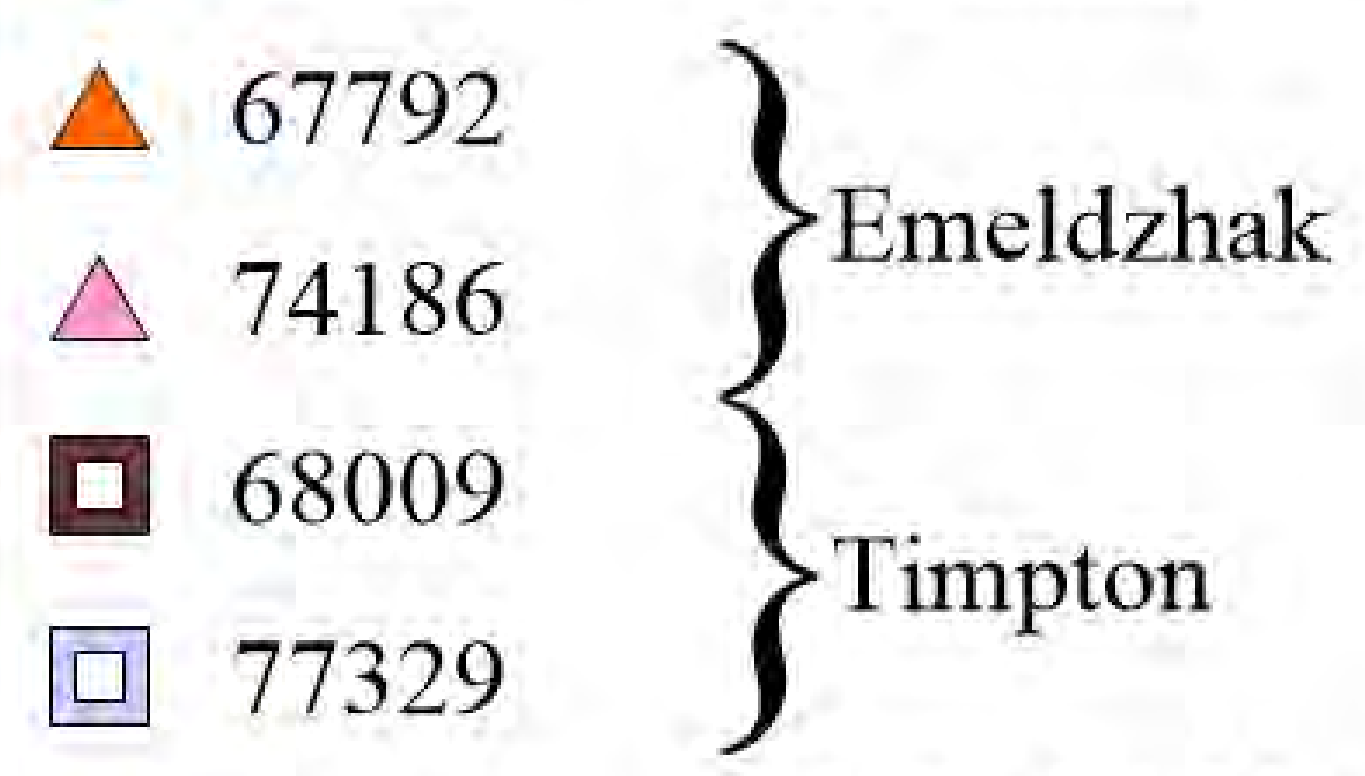

$\square 32900 \quad$ Nikolai-Maximilian

$\nabla 50363$ Hodzha-Achkan

X $81924 \quad$ Slyudyanka

- Magmatic

- Mantle

-.. $\mathrm{Fe} / \mathrm{Zn}$ 